\title{
Financial Development and Macroeconomic Performance: A Cointegration Approach
}

\author{
Cândida Ferreira \\ UECE - Research Unit in Complexity and Economics \\ REM - Research in Economics and Mathematics \\ ISEG, UL - Lisbon School of Economics and Management \\ Universidade de Lisboa, Rua Miguel Lupi, 20, 1249-078 Lisboa, Portugal \\ Tel: 351-213-925-912Ｅ-mail: candidaf@iseg.ulisboa.pt
}

Received: November 4, 2021 Accepted: December 15, $2021 \quad$ Published: X, 2021

doi:10.5296/ber.v11i4.19340～URL: https://doi.org/10.5296/ber.v11i4.19340

\begin{abstract}
The paper tests the existence of long-term relations between all the IMF financial development indices and some macroeconomic performance indicators applying panel cointegration tests in a panel with 46 countries, and in a panel including only the sub-sample of the 27 EU countries over the interval 1990-2019. Overall, there are no significant differences between the results obtained for the whole sample and the panel including only the EU countries. The results obtained clearly point to the existence of cointegration between the financial development indices and the real Gross Domestic Product, as well as with the inflation, the unemployment rate, the current account, and the net international investment position. The results also show that there are no significant differences between the results obtained for the financial institutions and for the financial markets indices. Moreover, the results related to the specific aspects addressed by the IMF indices very well demonstrate that much more important than the simple access to or the depth of the financial institutions and markets is the efficiency of these institutions and markets.
\end{abstract}

Keywords: Financial development, IMF Financial development indices, Macroeconomic performance, Cointegration, Panel cointegration tests

\section{Introduction}

Well-functioning banking institutions and financial markets are usually considered important and necessary to ensure that credit sectors play their specific role in the processes of economic development, contributing to economic growth, namely by decreasing transaction 
costs and the problems connected to asymmetric information.

There is a large strand of literature, going back to at least to Schumpeter (1911), who maintained that the services provided by financial intermediaries are essential to economic innovation, productive investment, and economic growth. During the last decades, the importance of the banking sector performance to economic growth has been subject of intense theoretical debates and empirical studies, particularly, after the important King and Levine contributions (namely the renowned papers King and Levine 1993-a, 1993-b).

Despite the overall accepted consensus that financial development is relevant to economic growth, several studies (at least since Khan and Senhadji, 2000) underline that the size of the effects may vary with the estimation methods, data frequency, the defined functional forms of the relationships and very particularly with the variables chosen as financial development indicators.

The relevance of the indicators chosen to represent financial development is very well highlighted, for example, in Sahay et al (2015) who developed a new very encompassing financial index that is also very clearly presented and discussed in Svirydzenka (2016). The new financial development index includes nine indices reflecting three dimensions: the depth, the access, and the efficiency of the financial markets and institutions and is nowadays provided by the International Monetary Fund (IMF).

This paper seeks to contribute to the literature by analysing the cointegration of these nine financial indices with the macroeconomic performance, represented not only by the real Gross Domestic Product (GDP), but also by other relevant macroeconomic indicators, namely the inflation (proxied by the GDP deflator), the unemployment rate, the current account, and the net international investment position over the period 1990-2019. Using two of the most popular panel cointegration tests: the Pedroni $(1999,2004)$, and the Westerlund (2007) tests, the paper first considers a panel with 46 countries and then a panel including only the sub-sample of the $27 \mathrm{EU}$ countries, aiming to test the robustness of the estimates, and questioning if the process of the European integration stimulates (or not) the cointegration between the financial development and the macroeconomic performance during the last decades.

The results obtained show that financial development is clearly cointegrated with all the indicators measuring macroeconomic performance. A detailed analysis of the results demonstrates that overall, cointegration with the Financial Markets Index is at least as strong as the cointegration with the Financial Institutions Index, indicating that the macroeconomic performance of the considered countries is clearly cointegrated not only with the development of the financial institutions but also with the development of the financial markets. Another relevant conclusion is that the efficiency of both the financial institutions and the financial markets are much more cointegrated with the economic performance of the considered countries than the simple access or the depth of the financial institutions and markets.

Finally, the results obtained for Panel 1 (including all the countries of the sample) are in line 
with the results obtained for Panel 2 (considering only the 27 EU countries) demonstrating the overall robustness of the results. Moreover, in what regards to the cointegration between the financial development and the macroeconomic performance there are no significant differences between the behaviour of the EU countries and the other countries included in the sample.

The remainder of this paper is organised as follows: Section 2 provides a brief literature review: Section 3 describes the methodological aspects and the used data; Section 4 presents and discusses the results obtained; Section 5 concludes.

\section{Brief Literature Review}

There is a strand of literature pointing to the consensus that well-functioning banking institutions and financial markets contribute positively to economic growth, particularly after the renowned contributions of King and Levine (1993-a) where the authors examine a cross-section of about 80 countries for the period 1960-89 finding that various measures of financial development are strongly associated with economic growth. They underline that each of the considered measures has shortcomings, but they all allow the relevant conclusion that finance matters, empirically confirming the Schumpeter's view that the services provided by financial intermediaries stimulate long-run growth. This conclusion was corroborated in King and Levine (1993-b) with the construction of an endogenous growth model and the overall conclusion that financial systems are important for productivity growth and economic development because good financial systems improve the probability of successful innovation and thereby accelerate economic growth, while financial sector distortions reduce the rate of economic growth by reducing the rate of innovation.

Following this strand of literature Levine and Zervos (1998) considered data for 49 countries, over the interval 1976-1990, concluding that there was a strong correlation between the rates of real per-capita output growth and stock market liquidity. Also, Demirgüç-Kunt and Levine (1999), using data for 150 countries spanning the 1990s, demonstrated that wealthy countries had developed financial systems better and defined this development in terms of the size and efficiency of the financial sector, measured by the assets, liabilities, overhead costs, and interest rate margins.

Beck et al (2004) considered the ratio between credits from financial intermediaries to the private sector divided by GDP as a proxy of financial intermediation in a panel of 52 countries during the period 1960 to 1999 , concluding that financial development was clearly pro-growth as well as pro-poor.

Greenwood et al $(2010,2013)$ empirically analysed the effects of financial development on economic growth, deploying a state cost verification model and concluded that as financial sector efficiency increased, financial resources got redirected from the less productive firms to their more productive peers. This analytical approach was applied to both US and cross-country data (more precisely, to a sample of 45 countries, that was first applied in Beck et al, 2000) and one of the key findings pointed to the conclusion that world output could increase by 53 per cent if all countries adopted the best global financial practices. 


\section{MInstitute ${ }^{\text {Mink }}$}

Business and Economic Research

ISSN 2162-4860

2021, Vol. 11, No. 4

Cecchetti and Kharroubi (2012) considered a sample of developed and emerging economies and analysed how financial development contributed to aggregate productivity growth and concluding in favour of an inverted U-shaped financial development effect, meaning that this development exerted a positive influence on productivity growth but only up to a certain point and after that point the influence on growth turned negative. Moreover, these authors focussed on advanced economies showing that a fast-growing financial sector could be detrimental to aggregate productivity growth. Corroborating these conclusions, Aizenman et al (2015), examining sector-level data in 41 economies found that finance increased economic growth, but only up to a point, concluding also that there were heterogeneous effects across sectors.

Several other studies, such as Bhide (1993) and Bencivenga et al (1995), had already underlined the existence of relevant costs associated with the role of financial intermediaries and that sometimes these intermediaries could be subject to adverse selection and moral hazard problems which would constrain real economic growth-enhancing resource allocation, exaggerating the increase in interest rates, or contributing to the decrease in the saving rates. Simultaneously, De Gregorio and Guidotti (1995) considered that high-income countries had reached a point at which financial depth could no longer contribute to increasing the efficiency of the investment.

Loayza and Rancière (2006) focused on the importance of the time horizon, supporting that, in the long-term, the studies on economic growth found a positive relationship between financial development and real growth; however, in the short term, the literature, and very particularly the one concerning bank crises, provided evidence of a negative relationship, revealing that monetary aggregates could represent good predictors of economic crisis. More recently, Laeven and Valencia (2013) confirmed the important role of credit market frictions to the performance of the real economic activity during the last global crisis, using a sample including a large cross section of firms from 50 countries in both advanced and emerging market economies.

Dabla-Norris et al (2015) analysed the sector-level productivity developments in the most advanced economies, considering the period from 1970 to 2007, concluding that before the last global financial crisis, the financial sector of the advanced economies was not orienting the resources towards the most productive economic sectors. Prochniak and Wasiak (2016) considered a sample of 28 EU and 34 OECD economies during the period of 1993-2013, taking into consideration the impact of the financial crisis on the relationship between finance and growth and concluding that an excessively large size of the financial system does not lead to more rapid economic growth, on the contrary, it may even negatively affect GDP growth.

Fetai (2018) tested the causality relations between economic growth and financial development, proxied by market capitalization, private sector credit and liquid liabilities, in 20 European countries, including Turkey and Russia, during 1998-2015, and validated the hypothesis that finance leads economic growth, showing also that financial crisis had a negative effect on real GDP per capita growth. Bijlsma et al (2018) performed a 
meta-analysis on 551 estimates from 68 empirical studies that take private credit to GDP as a measure for financial development, confirming that the analysed empirical studies on the finance-growth relationship show a wide range of estimated effects. They also concluded that overall, there was a positive but decreasing effect of financial development on growth.

Song et al (2021) used panel cointegration and panel error correction models to investigate the long run relationship among corruption, economic growth, and financial development (represented by broad money) in 142 countries over the interval 2002-2016, concluding that a long-term cointegration relationship exists in the full sample and very clearly in the sub-sample of developing countries, but not so evidently in the sub-sample of developed countries.

The provided examples clearly demonstrate that the contribution of the financial intermediaries to economic growth is far from consensual.

Khan and Senhadji (2000) had already stated that while the general effects of financial development on the real outputs might be considered positive, the size of these effects varied not only with the estimation methods, data frequency or the defined functional forms of the relationships but also with the variables chosen as financial development indicators. Corroborating these statements, Gaytan and Rancière (2004) concluded that, from one side, credit to the private sector and bank deposits contribute negatively to growth but, from another side, stock market size, liquidity and investment contribute positively to economic development. The same kind of conclusions were obtained by Ayadi et al (2013) using a sample of northern and southern Mediterranean countries for the 1985-2009 period, these authors confirmed that there are deficiencies in bank credit allocation in the considered countries as credit to the private sector and bank deposits are negatively associated to economic growth; however, on the stock market side, their results indicate that stock market size and liquidity do contribute to growth. Also, Cournède and Denk (2015) focusing on advanced countries, more precisely on OECD countries and G20 countries between 1970 and 2011, found that intermediated credit had a negative link with GDP growth and that stock market size had a positive one.

Law et al (2018) employed panel data models, considering a sample of 87 developed and developing countries for 1984 through 2014 and using three financial development indicators: private sector credit, liquid liabilities, and domestic credit, all expressed as ratios to GDP. The results obtained suggested that institutions played an important role in mediating the positive relationship between financial development and growth. The findings of this paper regarding the relevance of the institutions were corroborated by Nasreen et al (2020), who used panel data covering the period 1989-2016 to examine the role of financial globalization, institutions, and economic growth on the development of financial sector in 23 European countries, concluding that institutional quality was positively linked to financial development. Moreover, Nasreen et al (2020) underlined that the diversity of financial systems across countries implied that it is necessary to use multiple indicators to measure financial development.

The relevance of the indicators chosen to represent financial development had already been very clearly highlighted by Sahay et al (2015). Underlying that most of the empirical 
literature approximates financial development by the ratio of private credit to GDP, and to a lesser extent, by the stock market capitalization, also as a ratio of GDP, this study developed a financial index encompassing the banking and non-banking financial institutions as well as the financial markets across three dimensions: depth (size and liquidity), access (ability of individuals and companies to access financial services) and efficiency (ability of institutions to provide financial services at low costs and with sustainable revenues and the level of activities of financial markets). The Financial Development Index was also very clearly presented and well discussed in Svirydzenka (2016) and it is nowadays provided by the International Monetary Fund. This IMF database includes nine indices over 180 countries, with annual frequency from 1980 onwards (although not all the indices are available for all countries since 1980).

\section{Methodology and Data}

This paper discusses the potential influence of financial development on economic performance using panel data techniques which have the advantage of providing more informative data. More precisely, the paper opts to use panel cointegration techniques as cointegration provides an appropriate conceptual framework to analyse the long-term relationship between two series. The existence of cointegration implies that causality exists between the two series, although it does not indicate the direction of the causal relationship. The general definition of cointegration follows that of Engle and Granger (1987), meaning that two non-stationary series, $x_{t}$ and $y_{t}$, with the same order of integration, will be considered cointegrated (and long-term equilibrium relationships exist) if there is a stationary linear combination of these series, $z_{t}$, which can be defined using the equation $z_{t}=x_{t}-a-b y_{t}$ where $a$ and $b$ are constant terms.

Among the available panel cointegration tests, this paper choses two of the most popular ones: the Pedroni (1999, 2004), and the Westerlund (2007) tests.

Pedroni $(1999,2004)$ test the null hypothesis of no cointegration in non-stationary panels and can be regarded as a panel equivalent of the well-known Engle and Granger (1987) cointegration test applied in time series analysis. In general terms, Pedroni considers the following type of regression:

$$
y_{i t}=\alpha_{i}+\beta_{1 i} x_{1, i t}++\beta_{2 i} x_{2, i t}+\cdots+\beta_{M i} x_{M, i t}+e_{i t}
$$

where $y_{i t}$ is the variable being tested, $i=1, \ldots, N$ are the cross units, $t=1, \ldots, T$ the time periods, $m=1, \ldots, M$ are the independent variables, and $\alpha_{i}$ represents the fixed effects of the cross units. The variables are assumed to be integrated of order one for each cross unit $i$ of the panel and, under the null of no cointegration, the residual $e_{i t}$ will also be I(1). The test allows member specific effects and deterministic trends for the parameters $\alpha_{i}$ as well as individual variations of the slope coefficients, $\beta_{i}$, meaning that the cointegration vectors may be heterogenous across members of the panel.

Using the residuals from the static, long-run, regressions Pedroni provides seven specific 
panel cointegration test statistics. Four of them are panel statistics, based on pooling the residuals of the regressions along the within dimension of the panels: panel-v, panel-rho, panel-PP and panel-ADF statistics. The other three are group statistics, based on pooling the residuals along the between dimension of the panels: group-rho, group- $P P$ and group- $A D F$ statistics.

It is expected that the panel-v statistics departure from the positive infinity and that all the other six statistics adhere to the minus infinity. However, as clearly recognised, for example, in Neal (2014) the relative power of these seven Pedroni statistics is not totally clear, and they can even provide contradictory results. Nevertheless, similar results of several of these seven statistics can be interpreted as a sign of robustness of the Pedroni's panel cointegration test results.

The Westerlund (2007) panel cointegration test is also derived under the null hypothesis of no cointegration, but contrary to the Pedroni test, this test is not based on the residuals of the long-run static regressions. The Westerlund test is based on structural rather than residual dynamics and assesses the significance of the adjustment coefficient in an error corrector model of the following type:

$$
\begin{gathered}
\operatorname{Dyi}_{i t}=c_{i}+a_{i 1} * D y_{i t-1}+\cdots+a_{i p} * D y_{i t-p}+b_{i 0} * D x_{i t}+b_{i 1} * D x_{i t-1}+\cdots+b_{i p} * \\
D x_{i t-p}+a_{i}\left(y_{i t-1}-b_{1} * x_{i t-1}\right)+u_{i t}
\end{gathered}
$$

The test is very flexible and works well in unbalanced, heterogeneous and/or relatively small panels, allowing for dependence both between and within the cross-panel units. It provides four test statistics: $G_{t}, G_{a}, P_{t}$ and $P_{a}$. The $G_{t}$ and $G_{a}$ statistics test $H_{0}: a_{i}=0$ for all $i$ versus $H_{a}$ : $a_{i}<0$ for at least one of the series, $i$, starting from a weighted average of the individually estimated coefficients $a_{i}$ and their respective t-ratios. The $P_{t}$ and $P_{a}$ test statistics consider the pooled information of all panel cross-section units to test $H_{0}: a_{i}=0$ for all $i$ versus $H_{a}: a_{i}<0$ for all cross-section units.

The paper considers 46 countries: Argentina, Australia, Austria, Belgium, Brazil, Bulgaria, Canada, China, Croatia, Cyprus, Czech Republic, Denmark, Estonia, Finland, France, Germany, Greece, Hungary, Iceland, India, Indonesia, Ireland, Italy, Japan, Republic of Korea, Latvia, Lithuania, Luxembourg, Malta, Mexico, Netherlands, New Zealand, Norway, Poland, Portugal, Romania, Russian Federation, Slovak Republic, Slovenia, South Africa, Spain, Sweden, Switzerland, Turkey, United Kingdom, and United States, over the interval 1990-2019. All the data used in this paper are sourced from the IMF databases and the paper tests the cointegration between all the IMF financial development indices and some performance indicators, presented in Table 1. 
Table 1. Used data ${ }^{(*)}$

\begin{tabular}{|c|c|}
\hline Financial indices $^{(* *)}$ & Macroeconomic indicators ${ }^{(* * *)}$ \\
\hline Financial Development Index & Gross Domestic Product \\
\hline Financial Institutions Access Index & Deflator \\
\hline Financial Institutions Depth Index & Unemployment rate \\
\hline Financial Institutions Efficiency Index & Current account \\
\hline Financial Institutions Index & Net international investment position \\
\hline Markets Access Index & \\
\hline Financial Markets Depth Index & \\
\hline Financial Markets Efficiency Index & \\
\hline Financial Markets Index & \\
\hline
\end{tabular}

(*) All data are sourced from the IMF databases.

(**) The construction of these IMF financial development indices are very well explained in Sahay et al (2015) and in Svirydzenka (2016).

(***) More precisely, the Gross Domestic Product is the natural logarithm of the "Gross Domestic Product, Volume, Seasonally Adjusted" $(2010=100)$, and the Deflator is the natural logarithm of the "Gross Domestic Product, Deflator, Seasonally Adjusted" (2010=100), both sourced from the National Accounts, Constant Prices, Seasonally Adjusted, of the International Financial Statistics (IFS). The Unemployment rate is the "Labour Markets, Unemployment Rate, Percent", sourced from the Prices, Production and Labour selected indicators of the International Financial Statistics (IFS). The Current account is sourced from the Balance of Payments Standard Presentation (Millions of U.S. Dollars). The Net international investment position (Millions of U.S. Dollars) provides the "value of the financial assets of the residents of an economy that are claims on non-residents or are gold bullion held as reserve assets; and the liabilities of the residents of an economy to non-residents" and the data were extracted from IMF Data Warehouse.

\section{Empirical Results}

Aiming to analyse the possible existence of long-run relationships between each of the variables representing the macroeconomic performance of the considered countries and each of the IMF financial development indices for these countries the paper uses the two popular panel cointegration tests that are presented in the previous section: Pedroni, and Westerlund tests. These tests are applied to two panels: Panel 1 considers all the 46 countries included in the sample, and Panel 2 includes only the sub-sample of the 27 EU countries, over the interval 1990-2019.

Before proceeding with the panel cointegration tests the paper analyses the stationarity of the series using two widely recommended panel unit root tests: Levin-Lin-Chu test (Levin et al, 2002), and Hadri Lagrange multiplier tests (Hadri, 2000). According to the results reported in Appendix B, many of the considered variables are not stationary at their levels, but all of them are stationary at their first differences, and therefore it is possible to admit that they are integrated in the order one. Moreover, there are no remarkable differences between the results obtained for Panel 1 (including the whole sample of 46 countries) and for Panel 2 (including only the sub-sample of the 27 EU countries). 


\section{Macrothink}

The results obtained with the panel cointegration tests for Panel 1 are reported in Table 2 . Overall, it is possible to conclude that there is evidence of relevant cointegration and that the results obtained either with Pedroni or with Westerlund tests do not reveal significant differences. Nevertheless, and not surprisingly, the robustness of the seven specific statistics provided by the Pedroni test is not always the same; the same occurs in the four statistics obtained with the Westerlund test.

The first evident conclusion of the results presented in Table 2 is that cointegration between the overall financial index, more precisely the Financial Development Index, and all the five indicators representing macroeconomic performance should not be rejected. The results obtained for this overall IMF Financial Development Index suggest strong cointegration not only with the real GDP (that is usually considered in the empirical analyses of the relevance of financial development to economic growth) but also with the deflator, the unemployment rate, the current account, and the net international investment position.

There is also evidence of strong correlation between the index that summarizes the relevance of the financial institutions, the IMF Financial Institutions Index, and the five macroeconomic indicators.

In what regards to the specific aspects of the financial institutions (in terms of access, depth, and efficiency, as described in Appendix A), the results obtained reveal strong cointegration between the Financial Institutions Access Index and the real GDP, and to some extend also with the net international investment position but not so strong cointegration with the deflator, the current account, and the unemployment rate. Moreover, the cointegration of the Financial Institutions Depth Index with the real GDP, the deflator and the net international investment position is rather strong, but it decreases in what regards to the current account and particularly to the unemployment rate. 


\section{Macrothink}

Business and Economic Research

ISSN 2162-4860

Table 2. Results obtained with panel cointegration tests - PANEL 1

\begin{tabular}{|c|c|c|c|c|c|c|c|c|c|c|c|}
\hline $\begin{array}{l}\text { Gross Domestic Product } \\
\text { And }\end{array}$ & \multicolumn{7}{|l|}{ Pedroni } & \multicolumn{4}{|c|}{ Westerlund } \\
\hline Financial Development Index & $2.498 * * *$ & $-3.681 * * *$ & $-5.199 * * *$ & $-3.388 * * * *$ & $-2.757 * * *$ & $-5.855 * * *$ & $-3.817 * * * *$ & $-2.836 * * *$ & $-11.900 * * *$ & $-21.759 * * *$ & $-12.098 * * *$ \\
\hline Financial Institutions Access Index & $273^{*}$ & $-1.445^{*}$ & $-3.04 * * *$ & $-1.213^{*}$ & -.29 & $-3.249 * * *$ & -.1972 & $-2.448 * * *$ & $-8.874 * *$ & $-23.291 * * *$ & $-10.987 * * *$ \\
\hline Financial Institutions Depth Index & $12 * *$ & $-2.705 * * *$ & $-3.92 * * *$ & $-3.494 * * *$ & $-1.684 * *$ & $-4.112 * * *$ & $-2.715 * * *$ & $-2.440 * * *$ & $-10.024 * * *$ & $-16.643 * * *$ & $-9.581 * * *$ \\
\hline Financial Institutions Index & $3.031 * * *$ & $-3.977 * * *$ & $-5.533 * * *$ & $-2.667 * * *$ & $-2.871^{* * * *}$ & $-6.548 * * *$ & $-2.118^{* *}$ & $-2.878 * * *$ & $-12.342 * * *$ & $-29.193 * * *$ & $-17.614 * * *$ \\
\hline Financial Markets Access Index & $2.545 * * *$ & $-5.112 * * *$ & $-6.651^{* * * *}$ & $-5.356 * * *$ & $-3.521^{* * * *}$ & $-6.843 * * *$ & $-5.112 * * *$ & $-2.838 * * * *$ & $-10.877 * * *$ & $-16.373 * * *$ & $-8.603 * * * *$ \\
\hline Financial Markets Depth Index & .1645 & -.6895 & $-2.067^{* *}$ & $-1.774 * *$ & .6729 & $-1.723 * *$ & $-1.915 * *$ & $-2.200 * * *$ & $-9.040 * * *$ & $-11.430 *$ & $-6.466 * * *$ \\
\hline Financial Markets Eff & $3.828 * * *$ & $-5.34 * * *$ & $-6.27 * * *$ & $-4.249 * * *$ & $-3.875 * * *$ & $-6.814 * * *$ & $-4.638 * * *$ & $-3.584 * * *$ & $-15.240 * * *$ & $-19.897 * * *$ & $-11.169 * * *$ \\
\hline Financial Dev & $4.557 * * *$ & $-5.951 * * *$ & $-6.423 * * *$ & $-5.21 * * *$ & $-4.488^{* * * *}$ & $-6.811 * * *$ & $-5.053 * * *$ & $-2.513 * * *$ & $-9.597 * * *$ & $-17.883 * * *$ & $-9.701 * * *$ \\
\hline itutions Access Index & $2.349 * *$ & $-1.649 * *$ & $-2.515 * * *$ & $-1.156^{*}$ & -.3148 & $-2.336 * *$ & $-1.197 *$ & $-2.097 * * *$ & -7.312 & $-17.831 * * *$ & $-8.351^{* * * *}$ \\
\hline Financ & $2.932 * * *$ & $-2.856 * * *$ & $-3.668 * * *$ & $-2.508 * * *$ & -.8372 & $-2.835 * * *$ & $-2.163 * *$ & $-2.459 * * *$ & $-9.543 * * *$ & $-16.863 * * *$ & $-8.842 * * * *$ \\
\hline Financial Institt & $4.587 * * *$ & $-8.591 * * *$ & $-9.656 * * *$ & $-9.559 * * *$ & $-7.293^{* * * *}$ & $-10.61 * * *$ & $-9.152 * * *$ & $-2.834 * * * *$ & $-11.338 * * *$ & $-21.253 * * *$ & $-13.194 * * *$ \\
\hline Financial Ir & $3.335 * * *$ & $-4.084 * * *$ & $-5.3 * * *$ & $-3.744 * * *$ & $-3.217^{* * * *}$ & $-6.236 * * *$ & $-3.124 * * *$ & $-2.404 * * *$ & $-8.859 * *$ & $-21.251 * * *$ & $-12.330 * * *$ \\
\hline Financial N & $4 * * *$ & **** & $-6.721 * * *$ & $-5.423 * * *$ & $-4.263^{* * * *}$ & $-7.083 * * *$ & $-5.491 * * *$ & $-2.827 * * * *$ & $-10.691 * * *$ & $-16.711 * * *$ & $-8.255^{* * * *}$ \\
\hline Financial $\mathrm{M}$ & & $-2.223 * *$ & $-3.223 * * *$ & $-3.573 * * *$ & -.9734 & $-3.087 * * *$ & $-4.262 * * *$ & $-2.227 * * *$ & $-8.708 * *$ & $-11.779 * *$ & $-5.795^{* *}$ \\
\hline Financial $\mathrm{M}$ & $5.843 * * *$ & $-8.536 * * *$ & $-8.595^{* * * *}$ & $-7.996 * * *$ & $-5.762 * * *$ & $-8.494 * * *$ & $-8.206 * * *$ & $3.786 * * *$ & $-16.129 * * *$ & $-21.556 * * *$ & $-11.439 * * *$ \\
\hline Financi & .2698 & -.3654 & $-1.496 * *$ & -.9615 & .5 & *** & & -1 . & -5.964 & $-11.761 * *$ & -4.542 \\
\hline Financial Institutions E & $1.609 * *$ & $-4.909 * * *$ & $-6.567 * * *$ & $-4.372 * * *$ & $-3.779 * * *$ & $-7.554 * * *$ & $-4.4 * * *$ & $-2.733 * * *$ & $-10.888 * * *$ & $-24.194 * * *$ & $-12.707 * * *$ \\
\hline Financial Institutions Index & -.06817 & $-1.654 * *$ & $-3.679 * * *$ & $-1.762 * *$ & $-1.456^{*}$ & $-5.298 * * *$ & $-1.618 * *$ & $-2.242 * * *$ & -6.713 & $-22.126 * * *$ & $-8.561 * * *$ \\
\hline Financial N & & $-3.428 * * *$ & $-5.5 * * *$ & $-3.769 * * *$ & $9 * * *$ & $11^{* * * *}$ & $-3.798 * * *$ & $-2.561 * * *$ & $-9.991 * * *$ & $-16.395 * * *$ & $-8.068 * * *$ \\
\hline Financial $\mathrm{N}$ & -1 . & .4972 & -.965 & .004717 & & & .3519 & -1.855 & -5.907 & -10.519 & -4.026 \\
\hline Financial Markets Ef & $2.844 * *$ & $-4.863 * * *$ & $-5.766 * * *$ & $-4.822 * * *$ & $-2.925 * * *$ & $-5.704 * * *$ & $-4.223 * * * *$ & $-3.546 * * *$ & $-15.708 * * *$ & $-18.978^{* * * *}$ & $-10.223 * * * *$ \\
\hline Financial Markets Index & .417 & $-1.461 * *$ & $-2.803 * * *$ & $-1.918 * *$ & -.2814 & $-2.61 * * *$ & $-1.963 * *$ & $-2.461 * * *$ & $-8.474 *$ & $-15.064 * * *$ & $-6.371 * * *$ \\
\hline \multicolumn{12}{|l|}{ Current account and } \\
\hline Financial Development Index & $1.616 * *$ & $-3.038 * * *$ & $-4.904 * * *$ & $-4.354 * * *$ & $-2.672 * * *$ & $-5.904 * * *$ & $-5.153 * * *$ & $-2.491 * * *$ & -8.201 & $-18.261 * * *$ & $-7.783 * * *$ \\
\hline Final & & 4616 & & & & $-3.448 * * *$ & & $-2.378 * * *$ & -6.754 & $-20.372 * * *$ & $-6.847 * * * *$ \\
\hline Financial Institutions De & $1.401 *$ & $-2.474 * * *$ & $-3.757 * * *$ & $-2.415^{* *}$ & $-1.228 *$ & $-3.809 * * *$ & $-2.281 * *$ & -1.928 & -6.082 & $-14.345 * * *$ & $-6.071 * * *$ \\
\hline Financial Institutions Efficiency Inde & $1.916^{* * *}$ & $-4.98 * * *$ & $-7.217^{* * * *}$ & $-5.764 * * *$ & $-5.125^{* * * *}$ & $-9.376 * * *$ & $-5.887 * * *$ & $-2.691 * * *$ & $-11.204 * * *$ & $-22.321 * * *$ & $-11.360^{* * * *}$ \\
\hline & .7938 & $-2.625 * * *$ & & $-3.268^{* * * *}$ & & $-7.725 * * *$ & $-5.759 * * *$ & $-2.354 * * *$ & -7.335 & $-22.766 * * *$ & $-9.119 * * *$ \\
\hline Financial Markets Access Index & $1.3^{*}$ & $-3.658 * * *$ & $-5.671 * * *$ & $-3.758 * * *$ & $-2.849 * * * *$ & $-6.256 * * *$ & $-3.662 * * *$ & $-2.490 * * *$ & $-9.521 * * *$ & $-14.505 * * *$ & $-7.356 * * *$ \\
\hline Financial Markets Depth Index & -1.088 & .3059 & $-1.502 * *$ & $-1.961 * *$ & 1.447 & -1.056 & $-1.779 * *$ & -1.779 & -5.690 & -10.226 & -4.053 \\
\hline
\end{tabular}




\begin{tabular}{|c|c|c|c|c|c|c|c|c|c|c|c|}
\hline Financial Institutions Depth Index & $2.553 * * *$ & $-3.612 * * *$ & $-5.226 * * *$ & $-4.843 * * *$ & $-2.13 * *$ & $-5.368 * * *$ & $-4.929 * * *$ & $-2.310 * * *$ & $-8.854 * *$ & $-13.740^{* * *}$ & $-6.347 * * *$ \\
\hline Financial Institutions Index & $3.129 * * *$ & $-4.822 * * *$ & $-6.49 * * *$ & $-4.438 * * *$ & $-3.833^{* * * *}$ & $-7.782 * * * *$ & $-4.567 * * *$ & $-2.594 * * *$ & $-10.059 * * *$ & $-24.286 * * *$ & $-12.365 * * *$ \\
\hline Financial Markets Access Index & $2.391 * *$ & $-4.459 * * *$ & $-6.124 * * *$ & $-5.203 * * *$ & $-2.936^{* * * *}$ & $-6.297 * * * *$ & $-5.431 * * *$ & $-2.456 * * *$ & $-9.494 * * *$ & $-14.650 * * *$ & $-7.150 * * *$ \\
\hline Financial Markets Depth Index & .8899 & $-1.798 * *$ & $-3.271 * * *$ & $-4.014 * * *$ & -.3278 & $-3.085 * * * *$ & $-4.621 * * *$ & -1.910 & -6.395 & -9.681 & -3.671 \\
\hline Financial Markets Index & $2.061 * *$ & $-3.523 * * *$ & $-4.89 * * *$ & $-4.685 * * *$ & $-1.98 * *$ & $-4.871 * * *$ & $-5.475^{* * * *}$ & $-2.148 * * *$ & -7.888 & $-12.251 * * *$ & $-5.347 *$ \\
\hline
\end{tabular}

Source: Author's calculation. ***significant at 1\% level; ** significant at 5\% level; * significant at $10 \%$ level. Panel 2 includes all the 46 countries of the sample.

Finally, the results obtained for the Financial Institutions Efficiency Index clearly point to the existence of strong cointegration between this index and all the five indicators of macroeconomic performance, demonstrating that in all considered situations, the efficiency of the banking institutions (that is, their ability to provide financial services at low costs) is much more relevant to economic performance than the simple access (more precisely, the ability of individuals and companies to access financial services) or the depth (meaning, the size and liquidity) of these institutions.

The same kind of analysis, but now looking at the results obtained for the financial markets, indicates that the overall IMF Financial Markets Index is also clearly cointegrated with the real GDP, as well as with the other four measures of macroeconomic performance.

A more careful analysis of the specific aspects of the financial markets in terms of the access, depth, and efficiency, overall corroborates the conclusions obtained for the financial markets: the cointegrations between the IFM Financial Markets Efficiency Index and all the five macroeconomic performance indicators are much stronger than those obtained for the Financial Markets Access Index and the Financial Markets Depth Index. Moreover, in what regards to the depth index, it is even possible to reject its cointegration with the unemployment rate, almost always with the current account, and although not so clearly, also with the net international position.

The results obtained for Panel 2 (considering only the EU countries) are reported in Table 3 and are mostly in line with those obtained for Panel 1 (that includes all the 46 countries considered in the sample). As before, there is clear evidence of strong cointegration between the overall Financial Development Index and all the five variables representing macroeconomic performance.

Table 3. Results obtained with panel cointegration tests - PANEL 2

\begin{tabular}{|c|c|c|c|c|c|c|c|c|c|c|c|}
\hline \multirow{2}{*}{$\begin{array}{l}\text { Gross Domestic Product } \\
\text { And }\end{array}$} & \multicolumn{7}{|l|}{ Pedroni } & \multicolumn{4}{|l|}{ Westerlund } \\
\hline & Panel-v & $\begin{array}{l}\text { Panel-rho } \\
\end{array}$ & Panel-PP & Panel-ADF & Group-rho & Group-PP & Group-ADF & Gt & $\mathbf{G a}$ & $\mathbf{P t}$ & $\mathbf{P a}$ \\
\hline Financial Development Index & $2.817^{* * * *}$ & $-4.636 * * *$ & $-5.742^{* * * *}$ & $-4.025 * * *$ & $-3.742 * * *$ & $-6.402 * * *$ & $-3.021 * * *$ & $-2.993 * * *$ & $-13.228 * * *$ & $-17.638^{* * * *}$ & $-13.787^{* * * *}$ \\
\hline Financial Institutions Access Index & $1.51^{* *}$ & $-2.158 * *$ & $-3.511^{* * * *}$ & $-1.313^{*}$ & $-1.261 *$ & $-3.803 * * *$ & $-1.336^{*}$ & $-2.823 * * *$ & $-11.127^{* * *}$ & $-19.061 * * *$ & $-12.672^{* * * *}$ \\
\hline Financial Institutions Depth Index & $1.886 * *$ & $-2.721 * * * *$ & $-3.657 * * * *$ & $-3.488^{* * * *}$ & $-1.753^{* *}$ & $-3.789 * * *$ & $-2.422 * *$ & $-2.473 * * *$ & $-9.890 * * *$ & $-13.544 * * *$ & $-10.221^{* * *}$ \\
\hline Financial Institutions Efficiency Index & $3.642 * * *$ & $-7.132 * * *$ & $-8.722^{* * * *}$ & $-7.22 * * *$ & $-5.93 * * * *$ & $-9.889 * * *$ & $-7.681 * * * *$ & $-2.534 * * *$ & $-11.660 * * *$ & $-16.351 * * *$ & $-14.356^{* * * *}$ \\
\hline
\end{tabular}




\section{Macrothink \\ IInstitute ${ }^{m}$}

Business and Economic Research

ISSN 2162-4860

2021, Vol. 11, No. 4

Financial Markets Access Index

Financial Markets Depth Index

Financial Markets Efficiency Index

Financial Markets Index

Deflator and

Financial Development Index

\begin{tabular}{l} 
Financial Institutions Access Index \\
\hline Financial Institutions Depth Index
\end{tabular}

Financial Institutions Efficiency Index

Financial Institutions Index

Financial Markets Access Index

Financial Markets Depth Index

\begin{tabular}{l}
\hline Financial Markets Efficiency Index \\
\hline Financial Markets Index \\
\hline
\end{tabular}

Financial Markets Index

Unemployment Rate and

\begin{tabular}{|l}
\hline Financial Development Index \\
\hline Financial Institutions Access Index \\
\hline
\end{tabular}

Financial Institutions Depth Index

Financial Institutions Efficiency Index

Financial Institutions Index

\begin{tabular}{|l}
\hline Financial Markets Access Index \\
\hline Financial Markets Depth Index \\
\hline
\end{tabular}

Financial Markets Efficiency Index

Financial Markets Index

Current account and

Financial Development Index

Financial Institutions Access Index

\begin{tabular}{l} 
Financial Institutions Depth Index \\
\hline Financial Institutions Efficiency Index \\
\hline
\end{tabular}

Financial Institutions Index

Financial Markets Access Index

Financial Markets Depth Index

Financial Markets Efficiency Index

Net international investment position and

Financial Development Index

Financial Institutions Access Index

\begin{tabular}{l} 
Financial Institutions Depth Index \\
\hline Financial Institutions Efficiency Index \\
\hline
\end{tabular}

Financial Institutions Index

Financial Markets Access Index

Financial Markets Depth Index

Financial Markets Efficiency Index

Financial Markets Index

\begin{tabular}{|c|c|c|c|c|c|c|c|c|c|c|}
\hline $2.218 * *$ & $-3.551 * * *$ & $-5.56 * * *$ & $-3.647 * * * *$ & $-3.683 * * * *$ & $-7.473 * * *$ & $-2.192 * *$ & $-2.781 * * *$ & $-12.242^{* * * *}$ & $-23.210^{* * * *}$ & $-19.075^{* * * *}$ \\
\hline $2.413 * *$ & $-3.875 * * *$ & $-4.564 * * *$ & $-3.15 * * *$ & $-2.943 * * *$ & $-4.876^{* * * *}$ & $-3.103 * * *$ & $-3.016 * * *$ & $-12.549 * * *$ & $-13.411 * * *$ & $-9.358 * * *$ \\
\hline-.2371 & .1292 & -.9657 & -.4078 & $1.162^{*}$ & -.4869 & .5724 & -1.997 & -8.062 & -8.181 & $-6.325^{* * *}$ \\
\hline $3.649 * * *$ & $-5.301 * * *$ & $-5.761 * * *$ & $-3.756 * * *$ & $-3.763 * * *$ & $-5.926 * * *$ & $-4.407 * * *$ & $-3.185 * * *$ & $-12.241 * * *$ & $-15.908 * * *$ & $-11.918^{*}$ \\
\hline
\end{tabular}

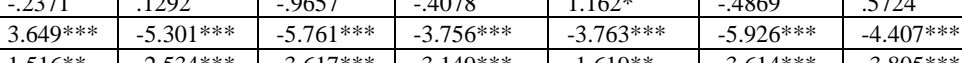

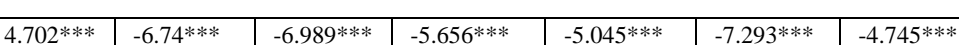

$-2.790^{* * * *}$

\begin{tabular}{|l|l|l|l|l|l|l|l|l|l|l|}
\hline $1.435^{*}$ & $-6.744^{* *}$ & $-6.989^{* * *}$ & $-5.656^{* * *}$ & $-5.045^{* * *}$ & $-7.293^{* * *}$ & $-4.745^{* * *}$ & $-2.769^{* * *}$ & $-10.687^{* * * *}$ & $-15.869^{* * *}$ & $-11.782^{* * * *}$ \\
\hline $2.767 *$ & -.5165 & $-2.393^{* *}$ & $-5.111^{* * *}$ & $-2 * *$ & $-2.575^{* * *}$ & $-9.521^{* * *}$ & $-15.906^{* * *}$ & $-10.456^{* * * *}$ \\
\hline
\end{tabular}

\begin{tabular}{l|l|l|l|l|l}
\hline $2.767^{* * * *}$ & $2.966^{* * *}$ & $-3.438^{* * * *}$ & $-2.382^{* * *}$ \\
\hline $3.127 * *$ & $-5.517 * *$ & $-6.855 *$ & $-6.01 *$ \\
\hline
\end{tabular}

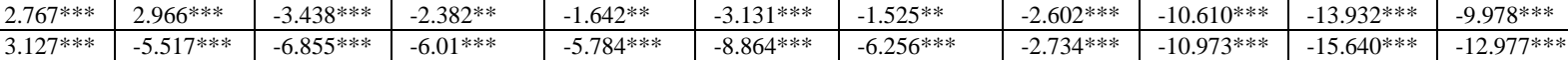

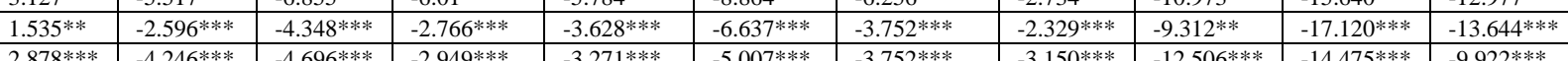

\begin{tabular}{|l|l|l|l|l|l|l}
\hline $2.878 * * *$ & $-4.246 * * *$ & $-4.696 * * *$ & $-2.949 * * *$ & $-3.271 * * *$ & $-5.007 * * *$ & $-3.752^{* * *}$ \\
\hline
\end{tabular}

\begin{tabular}{lllll|l|l|l}
\hline $1.206^{*}$ & $-1.245^{*}$ & $-1.957^{* *}$ & $-1.849^{* *}$ & .07828 & $-1.399^{*}$ & $-2.138^{* *}$ \\
\hline $5.556^{* * *}$ & $-8.152^{* * *}$ & $-7.799^{* * *}$ & $-5.431^{* * *}$ & $-5.618^{* * *}$ & $-7.65^{* * *}$ & $-5.088^{* * *}$ \\
\hline
\end{tabular}

\begin{tabular}{l|l|}
$-2.135 * *$ & -8.050 \\
\hline
\end{tabular}

$-9.158^{*}$

$-5.853^{* *}$

\begin{tabular}{|l|l|l|l|l|l|l|l|l|l|l|}
\hline $3.037^{* * *}$ & $-4.352^{* * *}$ & $-4.813^{* * *}$ & $-3.168^{* * *}$ & $-3.15^{* * *}$ & $-4.707^{* * *}$ & $-3.715^{* * *}$ & $-2.910^{* * *}$ & $-10.574^{* * *}$ & $-13.934^{* * *}$ & $-9.233^{* * * *}$ \\
\hline
\end{tabular}

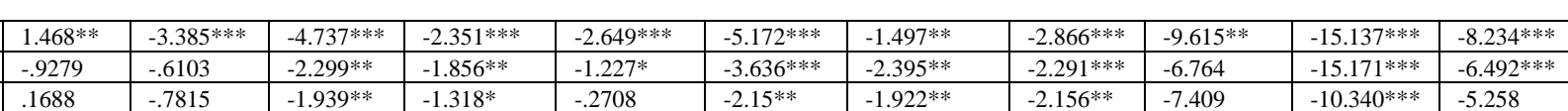

\begin{tabular}{l|l|l|l|l|l|l|l|l|l|l|}
.1688 & -.7815 & $-1.939^{* *}$ & $-1.318^{*}$ & -.2708 & $-2.15^{* *}$ & $-1.922^{* *}$ & $-2.156^{* *}$ & -7.409 & $-10.340^{* * *}$ & -5.258 \\
\hline .09865 & $-2.913^{* * *}$ & $-4.992 * * *$ & $-3.174^{* * *}$ & $-2.71^{* * *}$ & $-6.302 * * *$ & $-3.794^{* * *}$ & $-2.753 * * *$ & $-10.451 * * *$ & $-19.279^{* * * *}$ & $-12.833^{* * *}$ \\
\hline
\end{tabular}

\begin{tabular}{|l|l|l|l|}
\hline .09865 & $-2.913 * * *$ & $-4.992 * * *$ & $-3.174 * * *$ \\
\hline-.691 & $-1.304 *$ & $-3.513 *$ & $-1.164 *$ \\
\hline
\end{tabular}

\begin{tabular}{l|l|l|l|l|l|l}
-.6931 & $-1.304 *$ & $-3.513 * * *$ & $-1.164 *$ & $-1.684 * *$ \\
\hline
\end{tabular}

\begin{tabular}{l|l|l|l|l|l|l|l|l|l|l|l}
$-1.231^{*}$ & $-2.849^{* * *}$ & $-3.872^{* * *}$ & $-2.988^{* * *}$ & $-2.121^{* *}$ & $-4.062^{* * *}$ & $-2.449^{* * *}$ & $-2.501^{* * *}$ & $-9.599^{* * *}$ & $-11.463^{* * *}$ & $-7.079^{* * *}$ \\
\hline-1.355 & .7322 & -.7525 & -.2926 & 2.224 & .1222 & .2593 & -1.830 & -5.529 & -8.003 & -3.798 \\
\hline
\end{tabular}

\begin{tabular}{l|l|l|l}
.7322 & -.7525 & -.2926 \\
\hline$-4.269 * * * *$ & $-5.098^{* * * *}$ & $-3.762 * *$ \\
-1.109 & $-2.294 * 2$ & $-1.638 *$ \\
\hline
\end{tabular}

\begin{tabular}{l|l|l|l} 
& -9.5929 \\
\hline 930 & -5.529 \\
\hline
\end{tabular}

\begin{tabular}{l|l|l}
-11.063 & $-7.079 * \cdots$ \\
\hline-8.003 & -3.798
\end{tabular}

\begin{tabular}{l|l|l|l|l|l|l|}
-.08196 & -1.109 & $-2.294 * * *$ & $-1.638 * *$ & -.1388 & $-2.099 * *$ & -1.119 \\
\hline
\end{tabular}

\begin{tabular}{|c|c|c|c|c|c|c|c|c|c|c|}
\hline $1.983 * *$ & $-3.759 * * *$ & $-5.549 * * *$ & $-5.418 * * * *$ & $-3.56 * * *$ & $-7.198 * * *$ & $-5.285 * * * *$ & $-2.906 * * *$ & $-9.760 * * *$ & $-16.190^{* * * *}$ & $-9.025 * * * *$ \\
\hline .3759 & $-2.063 * *$ & $-3.679 * * *$ & -.9538 & $-2.106^{* * *}$ & $-5.261 * * *$ & -1.116 & $-2.984 * * *$ & $-8.598^{*}$ & $-17.628 * * *$ & $-7.737 * * * *$ \\
\hline $2.214 * *$ & $-3.733 * * *$ & $-4.664 * * *$ & $-3.539 * * *$ & $-2.832 * * * *$ & $-5.108 * * * *$ & $-3.349 * *$ & $-2.237 * * *$ & -7.173 & $-12.388 * * *$ & $-6.995 * * *$ \\
\hline .7441 & $-3.659 * * *$ & $-6.131 * * *$ & $-3.761 * * *$ & $-3.559 * * *$ & $-7.58 * * *$ & $-3.71 * * *$ & $-2.682 * * *$ & $-10.725 * * *$ & -17.759 *** & $-11.324 * * *$ \\
\hline .4566 & $-2.822 * * *$ & $-5.092 * * *$ & $-4.047 * * *$ & $-3.076^{* * * *}$ & $-7.002 * * * *$ & $-2.883 * * *$ & $-2.747 * * *$ & $\begin{array}{l}-8.412 \\
\end{array}$ & $-19.244 * * *$ & $-9.867 * * * *$ \\
\hline $2.307 * *$ & $-4.22 * * *$ & $-5.359 * * *$ & $-4.018 * * *$ & $-2.975^{* * * *}$ & $-5.36 * * *$ & $-4.171 * * *$ & $-2.536 * * *$ & $-10.140 * * *$ & $-11.642 * * *$ & $-7.831 * * *$ \\
\hline-.03125 & -1.043 & $-2.288^{* * *}$ & $-2.558 * * *$ & .4523 & $-1.53 * *$ & $-2.455 * * *$ & -1.712 & -5.199 & -7.712 & -3.637 \\
\hline $1.705 *$ & $-3.879 * * *$ & $-4.965 * * *$ & $-4.315 * * * *$ & $-2.61 * * *$ & $-5.072 * * * *$ & $-4.524 * * *$ & $-2.695 * * * *$ & $-10.772^{* * * *}$ & $-13.399 * * *$ & $-9.442^{* * * *}$ \\
\hline .5762 & $-2.394 * *$ & $-3.589 * * *$ & $-3.583 * * *$ & $-1.634 * *$ & $-3.527 * * * *$ & $-3.886 * * *$ & $-2.277^{* * * *}$ & -8.530 & -9.82 & $-5.565^{*}$ \\
\hline
\end{tabular}
.5762

\begin{tabular}{l|l}
$-2.6277^{* * * *}$ & -8.530 \\
\hline
\end{tabular}

\begin{tabular}{l|l|l}
$-9.828 * *$ & $-5.565^{*}$ \\
\hline
\end{tabular}

\begin{tabular}{|c|c|c|c|c|c|c|c|c|c|c|}
\hline $3.067 * * *$ & $-4.822 * * * *$ & $-5.647 * * * *$ & $-4.848 * * * *$ & $-3.679 * * *$ & $-6.07 * * *$ & $-3.385 * * *$ & $-2.849 * * *$ & $-11.696 * * *$ & $-14.420 * * *$ & $-8.961 * * * *$ \\
\hline $1.695 * *$ & $-2.142 * *$ & $-4.01 * * *$ & $-1.298^{*}$ & $-2.457 * * * *$ & $-5.841 * * * *$ & $-3.005 * * * *$ & $-3.074 * * *$ & $-11.406 * * *$ & $-20.393 * * *$ & $-13.329 * * *$ \\
\hline $1.888 * *$ & $-2.3^{* *}$ & $-3.273 * * * *$ & $-3.124 * * * *$ & $-1.324 *$ & $-3.259 * * *$ & $-2.993 * * * *$ & $-2.588 * * * *$ & $-10.232 * * *$ & $-11.569 * * *$ & $-7.681 * * *$ \\
\hline $1.583^{* *}$ & $-3.929 * * *$ & $-5.68 * * *$ & $-3.13^{* * * *}$ & $-4.117 * * *$ & $-7.653 * * * *$ & $-4.351^{* * * *}$ & $-2.848 * * *$ & $-12.808 * * *$ & $-17.139 * * *$ & $-13.856 * * *$ \\
\hline $1.444 * *$ & $-2.778 * * *$ & $-5.329 * * * *$ & $-5.207 * * * *$ & $-4.278 * * *$ & $-8.304 * * * *$ & $-7.199 * * *$ & $-2.896 * * *$ & $-11.429 * * *$ & $-21.409^{* * *}$ & $-14.929 * * *$ \\
\hline $1.879 * *$ & $-3.596 * * *$ & $-4.643 * * * *$ & $-3.315^{* * * *}$ & $-2.837 * * *$ & $-4.95 * * *$ & $-4.833^{* * * *}$ & $-2.627 * * *$ & $-10.577^{* * * *}$ & $-11.851^{* * *}$ & $-8.181^{* * * *}$ \\
\hline-.5992 & .6946 & -.07889 & .7536 & 1.906 & .6535 & .5344 & $\begin{array}{l}-1.769 \\
\end{array}$ & -5.665 & -7.258 & -3.656 \\
\hline $2.981 * * *$ & $-4.743 * * *$ & $-5.203 * * * *$ & $-4.424 * * * *$ & $-3.117 * * *$ & $-5.184 * * * *$ & $-4.606^{* * * *}$ & $-2.773 * * *$ & $-11.213 * * *$ & $-14.131^{* * *}$ & $-10.510^{* * *}$ \\
\hline .9298 & $-1.705 * *$ & $-2.459 * * *$ & $-2.892 * * *$ & -.7705 & $-2.333 * *$ & $-2.199 * *$ & $2.306 * * *$ & $-8.813 *$ & $-9.674 * *$ & $-5.804 * *$ \\
\hline
\end{tabular}

Source: Author's calculation. ***significant at $1 \%$ level; ** significant at $5 \%$ level; * significant at $10 \%$ level. Panel 2 includes the sub-sample of the 27 EU countries. 
In what regards to the IMF Financial Institutions Index, cointegration is also evident, although not so strong with the unemployment rate. Moreover, the results related to the specific aspects of the financial institutions (access, depth, and efficiency) overall confirm the conclusions already obtained for the previous panel. There is very strong cointegration between the Financial Institutions Efficiency Index and all the five macro performance indicators and not so strong cointegration of the Financial Institutions Access Index and the Financial Institutions Depth Index, and it is particularly weak in what regards to the unemployment rate. Overall, these results confirm that the efficiency of the banking institutions is much more relevant to the macroeconomic performance than the access or the depth of the banking institutions.

A more detailed analysis of the results obtained for the indices representing the access, the depth, and the efficiency of the financial markets, reinforce the previous conclusions. Now there is no clear evidence of relevant cointegration of the Financial Markets Depth Index with almost all the considered macroeconomic performance indicators (the only exception is the deflator); but there is strong and very strong evidence of the cointegration of the Financial Markets Access Index and the Financial Markets Efficiency Index with all the five of macroeconomic performance indicators.

Overall, the results obtained for Panel 2 confirm those obtained for Panel 1, providing evidence that in what regards to the cointegration between the different aspects of financial development and the macroeconomic performance there are no significant differences between the behaviour of the EU countries and the other countries included in the sample.

\section{Concluding Remarks}

This paper contributes to the literature confirming the existence of long-term (cointegration) relationships between all the nine indices, representing different aspects of the financial development, that are provided by the IMF and the five indicators that were chosen to measure macroeconomic performance in a sample of 46 countries over the period 1990-2019.

Applying two of the most popular panel cointegration tests the paper provides robust evidence of the existence of cointegration between the overall Financial Development Index, as well as of the Financial Institutions Index and the Financial Markets Index not only with the real GDP but also with the other macroeconomic performance indicators, namely the deflator, the unemployment rate and the two indicators related to the international performance: the current account and the net international investment position.

Moreover, the paper clearly underlines that in what regards to the cointegration with macroeconomic performance, more important than the simple access to the financial institutions and markets (meaning the ability of individuals and companies to access financial services), or the depth the financial institutions and markets (more precisely, their size and liquidity), is the efficiency of these financial institutions and markets, that is, the ability of the institutions to provide financial services at low costs and with sustainable revenues and the level of activities of financial markets.

Overall, the results obtained in this paper do not confirm the conclusions of some authors, 
namely Gaytan and Rancière (2004), Ayadi et al (2013), and Cournède and Denk (2015), regarding the existence of significant differences between the relevance of the financial institutions versus financial markets to economic growth.

The conclusions of this paper are mostly in line with the large strand of literature supporting that well-functioning financial institutions and markets are relevant to economic growth. These conclusions are particularly in line with those, such as Loayza and Rancière (2006), who focused on the importance of the time horizon, underlying that, in the long-term, the empirical studies on economic growth found a positive relationship between financial development and the real growth. This paper also supports the statements of Svirydzenka (2016) corroborating that the development and diversity of the financial systems across countries requires multiple indicators to measure financial development. The paper clearly concludes that, in the long-term, the development and specially the efficiency of both the financial institutions and financial markets, are strongly cointegrated not only with the real GDP but also with other relevant indicators of macroeconomic performance, such as the inflation, the unemployment rate, the current account, and the net international investment position.

\section{Acknowledgments}

The author acknowledges financial Support from FCT - Fundação para a Ciência e Tecnologia (Portugal), national funding through research grant UIDB/05069/2020.

The author is very grateful to the anonymous referee(s) for their encouraging comments as well as for the pertinent suggestions and recommendations that were provided. The usual disclaimer applies.

\section{References}

Aizenman, J., Jinjarak, Y., \& Park, D. (2015). Financial Development and Output Growth in Developing Asia and Latin America: A Comparative Sectoral Analysis. NBER Working Paper 20917 National Bureau of Economic Research, Cambridge, Massachusetts. https://doi.org/10.3386/w20917

Ayadi, R., Arbak, E., Ben-Naceur, S., \& De Groen, W. P. (2013). Financial Development, Bank Efficiency and Economic Growth across the Mediterranean, European Commission European Research Area. WP 6 - Financial services and capital markets, MEDPRO Technical Report No 30. https://doi.org/10.1007/978-3-319-11122-3_14

Beck, T., Demirgüç-Kunt, A., \& Levine, R. (2000). A new database on financial development and structure. World Bank Economic Review, 14, 597-605.

https://doi.org/10.1093/wber/14.3.597

Beck, T., Demirgüç-Kunt, A., \& Levine, R. (2004). Finance, Inequality and Poverty: Cross-Country Evidence. World Bank Policy Research Working Paper No. 3338. https://doi.org/10.1596/1813-9450-3338

Bencivenga, V., Smith, B., \& Starr, R. (1995). Transaction Costs, Technological Choice and 


\section{MInstitute ${ }^{\text {Mink }}$}

Endogenous Growth. Journal of Economic Theory, 67, 53-117.

https://doi.org/10.1006/jeth.1995.1069

Bhide, A. (1993). The Hidden Costs of Stock Market Liquidity. Journal of Financial Economics, 34, 1-51. https://doi.org/10.1016/0304-405X(93)90039-E

Bijlsma, M., Kool, C., \& Non, M. (2018). The effect of financial development on economic growth: a meta-analysis. Applied Economics, 50, 6128-6148.

https://doi.org/10.1080/00036846.2018.1489503

Cecchetti, S., \& Kharroubi, E. (2012). Reassessing the impact of finance on growth, Bank for International Settlements. Working Paper No. 381.

Cournède, B., \& Denk, O. (2015). Finance and Economic Growth in OECD and G20 Countries. OECD Economics Department Working Papers No. 1223.

https://doi.org/10.2139/ssrn.2649935

Dabla-Norris, E., Guo, S., Haksar, V., Kim, M., Kochhar, K., Wiseman, K., \& Zdzienicka, A. (2015). The New Normal: A Sector-Level Perspective on Growth and Productivity Trends in Advanced Economies. IMF Staff Discussion Note International Monetary Fund, Washington. https://doi.org/10.5089/9781498334181.006

De Gregorio, J., \& Guidotti. P. (1995). Financial Development and Economic Growth. World Development, 23, 433-48. https://doi.org/10.1016/0305-750X(94)00132-I

Demirgüç-Kunt, A., \& Levine, R. (1999). Bank-Based and Market-Based Financial Systems: Cross Country Comparisons. World Bank Policy Research Working Paper, No 2143.

Engle, R. F., \& Granger, C. W. J. (1987). Cointegration and error correction: Representation, estimation and testing. Econometrica, 55, 251-276. https://doi.org/10.2307/1913236

Fetai, B. T. (2018). Does financial development accelerate economic growth? An empirical analysis of European countries in transition. Journal of Financial Economic Policy, 10(3), 426-435. https://doi.org/10.1108/JFEP-11-2017-0118

Gaytan, A., \& Rancière, R. (2004). Wealth, Financial Intermediation and Growth. Departments of Economics and Business, Universitat Pompeu Fabra, Economics Working Papers No 851. https://doi.org/10.2139/ssrn.860925

Greenwood, J., Wang, C., \& Sanchez, J. M. (2010). Financing development: The role of information costs. American Economic Review, 100, 1875-1891.

https://doi.org/10.1257/aer.100.4.1875

Greenwood, J., Sanchez, J. M., \& Wang, C. (2013). Quantifying the impact of financial development on economic development. Review of Economic Dynamics, 16, 194-215. https://doi.org/10.1016/j.red.2012.07.003

Hadri, K. (2000). Testing for stationarity in heterogenous panel data. The Econometrics Journal, 3, 148-161. https://doi.org/10.1111/1368-423X.00043 
Khan, M. S., \& Senhadji, A. (2000). Financial Development and Economic Growth: An Overview. IMF Working Paper No 209. https://doi.org/10.5089/9781451874747.001

King, R., \& Levine, R. (1993-a). Finance and Growth: Schumpeter Might Be Right. Quarterly Journal of Economics, 108, 717-737. https://doi.org/10.2307/2118406

King, R., \& Levine, R. (1993-b). Finance, entrepreneurship and growth: theory and evidence. Journal of Monetary Economics, 32, 513-542.

https://doi.org/10.1016/0304-3932(93)90028-E

Laeven, L., \& Valencia, F. (2013). Systemic Banking Crises Database. IMF Economic Review, 61, 225-270. https://doi.org/10.1057/imfer.2013.12

Law, S. H., Kutan, A. M., \& Naseem, N. A. M. (2018). The role of institutions in finance curse: evidence from international data. Journal of Comparative Economics, 46(1), 174-191. https://doi.org/10.1016/j.jce.2017.04.001

Levin, A., Lin, C. F., \& Chu, C. S. (2002). Unit Root Tests in Panel Data: Asymptotic and Finite Sample Properties. Journal of Econometrics, 108, 1-24.

https://doi.org/10.1016/S0304-4076(01)00098-7

Levine, R., \& Zervos, S. (1998). Stock markets, banks and economic growth. American Economic Review, 88, 537-558. https://doi.org/10.1596/1813-9450-1690

Loayza, N. V., \& Rancière, R. (2006). Financial Development, Financial Fragility, and Growth. Journal of Money, Credit and Banking, 38, 1051-1076.

https://doi.org/10.1353/mcb.2006.0060

Nasreen, S., Mahalik, M. K., Shahbaz, M., \& Abbas, Q. (2020). How do financial globalization, institutions and economic growth impact financial sector development in European countries?. Research in International Business and Finance, 54, 101247.

https://doi.org/10.1016/j.ribaf.2020.101247

Neal, T. (2014). Panel cointegration analysis with xtpedroni. Stata Journal, 14, 684-692. https://doi.org/10.1177/1536867X1401400312

Pedroni, P. (1999). Critical values for cointegration tests in heterogeneous panels with multiple regressors. Oxford Bulletin of Economics and Statistics, 61, 653-670.

https://doi.org/10.1111/1468-0084.61.s1.14

Pedroni, P. (2004). Panel cointegration: Asymptotic and finite sample properties of pooled time series tests with an application to the PPP hypothesis. Econometric Theory, 20, 597-625. https://doi.org/10.1017/S0266466604203073

Prochniak, M., \& Wasiak, K. (2016). The impact of the financial system on economic growth in the context of the global crisis: Empirical evidence for the EU and OECD countries. Empirica, 44, 295-337. https://doi.org/10.1007/s10663-016-9323-9

Sahay, R., Cihak, M., N'Diaye, P., Barajas, A., Bi, R., Ayala, D., ... Yousefi, S. R. (2015) Rethinking Financial Deepening: Stability and Growth in Emerging Markets. IMF Staff 


\section{Macrothink}

Business and Economic Research

ISSN 2162-4860

2021, Vol. 11, No. 4

Discussion Note, SDN/15/08. https://doi.org/10.5089/9781498312615.006

Schumpeter, J. A. (1911). The Theory of Economic Development: An inquiry into profits, capital, credit, interest and the business cycle. Harvard University Press, Cambridge, Massachusetts (1st ed. in English, 1934).

Song, C-Q., Chang, C-P., \& Gong, Q. (2021). Economic growth, corruption, and financial development: Global evidence. Economic Modelling, 94, 822-830.

https://doi.org/10.1016/j.econmod.2020.02.022

Svirydzenka, K. (2016). Introducing a New Broad-based Index of Financial Development. IMF Working Paper, WP/16/5. https://doi.org/10.5089/9781513583709.001

Westerlund, J. (2007). Testing for Error Correction in Panel Data. Oxford Bulletin of Economics and Statistics, 69, 709-748. https://doi.org/10.1111/j.1468-0084.2007.00477.x

\section{Appendix}

Appendix A. Construction of the Financial Development Index

\begin{tabular}{|l|l|l|}
\hline & FINANCIAL INSTITUTIONS & FINANCIAL MARKETS \\
\hline DEPTH & 1. Private-sector credit (\% of GDP) & 1. Stock market capitalization to GDP \\
& 2. Pension fund assets (\% of GDP) & 2. Stocks traded to GDP \\
& 3. Mutual fund assets (\% of GDP) & 3. International debt securities government (\% of GDP) \\
& 4. Insurance premiums, life, and & 4. Total debt securities of nonfinancial corporations (\% of GDP) \\
& non-life (\% of GDP) & 5. Total debt securities of financial corporations (\% of GDP) \\
\hline ACCES & 1. Branches (commercial banks) & 1. Percent of market capitalization outside of top 10 largest companies \\
& per 100,000 adults & 2. Total number of issuers of debt (domestic and \\
EFFICI & 2. ATMs per 100,000 adults & 1. Net interest margin \\
& 2. Lending-deposits spread & capitalization) \\
& 3. Non-interest income to total income \\
& 4. Overhead costs to total assets & \\
5. Return on assets & \\
6. Return on equity & \\
\hline
\end{tabular}

Source: Sahay, R., Cihak, M., N'Diaye, P., Barajas, A., Bi, R., Ayala, D., Gao, Y., Kyobe, A., Nguyen, L., Saborowski, C., Svirydzenka, K. and Yousefi, S.R. (2015) Rethinking Financial Deepening: Stability and Growth in Emerging Markets, IMF Staff Discussion Note, SDN/15/08, pp. 34. 


\section{Macrothink}

Business and Economic Research

ISSN 2162-4860

2021, Vol. 11, No. 4

Appendix B. Results obtained with panel unit root tests (p-values)

\begin{tabular}{|c|c|c|c|c|c|c|c|c|}
\hline \multirow[t]{3}{*}{ Variables } & \multicolumn{4}{|c|}{ PANEL 1 } & \multicolumn{4}{|c|}{ PANEL 2} \\
\hline & \multicolumn{2}{|c|}{ Levin $\mathbf{L i}$} & \multicolumn{2}{|l|}{ Fisher } & \multicolumn{2}{|c|}{ Levin $\mathbf{L i}$} & \multicolumn{2}{|l|}{ Fisher } \\
\hline & Levels & Differences & Levels & differences & levels & differences & levels & differences \\
\hline Financial Development Index & 0.0000 & 0.0000 & 0.0000 & 0.0000 & 0.0000 & 0.0000 & 0.0000 & 0.0000 \\
\hline Financial Institutions Access Index & 0.5242 & 0.0000 & 0.0000 & 0.0000 & 0.0714 & 0.0000 & 0.0000 & 0.0000 \\
\hline Financial Institutions Depth Index & 0.0282 & 0.0000 & 0.0000 & 0.0000 & 0.0027 & 0.0000 & 0.0002 & 0.0000 \\
\hline Financial Institutions Efficiency Index & 0.0000 & 0.0000 & 0.0000 & 0.0000 & 0.0000 & 0.0000 & 0.0000 & 0.0000 \\
\hline Financial Institutions Index & 0.0000 & 0.0000 & 0.0000 & 0.0000 & 0.0000 & 0.0000 & 0.0000 & 0.0000 \\
\hline Markets Access Index & 0.0000 & 0.0000 & 0.0000 & 0.0000 & 0.0000 & 0.0000 & 0.0000 & 0.0000 \\
\hline Financial Markets Depth Index & 0.0000 & 0.0000 & 0.0052 & 0.0000 & 0.0002 & 0.0000 & 0.0898 & 0.0000 \\
\hline Financial Markets Efficiency Index & 0.0000 & 0.0000 & 0.0000 & 0.0000 & 0.0000 & 0.0000 & 0.0000 & 0.0000 \\
\hline Financial Markets Index & 0.0000 & 0.0000 & 0.0000 & 0.0000 & 0.0001 & 0.0000 & 0.0000 & 0.0000 \\
\hline Gross Domestic Product & 0.8132 & 0.0000 & 0.9993 & 0.0000 & 1.0000 & 0.0000 & 1.0000 & 0.0000 \\
\hline Deflator & 0.0000 & 0.0000 & 0.0000 & 0.0000 & 0.1019 & 0.0000 & 0.9995 & 0.0000 \\
\hline Unemployment Rate & 0.4034 & 0.0000 & 0.5464 & 0.0000 & 0.7594 & 0.0000 & 0.7472 & 0.0000 \\
\hline Current account & 0.1271 & 0.0000 & 0.1388 & 0.0000 & 0.8615 & 0.0000 & 0.0664 & 0.0000 \\
\hline Net international investment position & 1.0000 & 0.0000 & 1.0000 & 0.0000 & 1.0000 & 0.0000 & 1.0000 & 0.0000 \\
\hline
\end{tabular}

Source: Author's calculations.

\section{Copyright Disclaimer}

Copyright for this article is retained by the author(s), with first publication rights granted to the journal.

This is an open-access article distributed under the terms and conditions of the Creative Commons Attribution license (http://creativecommons.org/licenses/by/4.0/). 